Kudzayi Savious

Tarisayi

Postdoctoral Fellow, Geography Education, School of Education, Edgewood Campus, University of KwaZulu-Natal. Email: TarisayiK@ukzn. ac.za

DOl: https://dx.doi. org/10.18820/24150509/ JCH44.v1.5

ISSN 0258-2422 (Print) ISSN 2415-0509 (Online) Journal for Contemporary History 2019 44(1):90-106

(c) Creative Commons With Attribution (CC-BY)

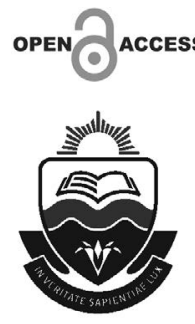

\section{DIVERGENT PERSPECTIVES ON THE LAND REFORM IN ZIMBABWE}

\begin{abstract}
A variety of views on land reform in Zimbabwe have emerged in recent years. The background to the discussion on the perspectives on the land reform revealed the significant contribution of the outcome of the February 2000 referendum on the Fast Track Land Reform Programme in Zimbabwe. This paper interrogates the various views on land reform in Zimbabwe under four dominant perspectives: the political perspective, livelihoods perspective, human rights perspective and agricultural perspective. The paper shows that there are divergent views within these dominant perspectives. One view within the political perspective holds that the government ruling party, the Zimbabwe African National Union-Patriotic Front (ZANU-PF), led by Robert Mugabe, manipulated demand for land to gain political mileage. Views within the political perspective further argue that land reform was used as a weapon against white farmers for allegedly supporting the Movement for Democratic Change (MDC) opposition party. There was no consensus on what happened to the livelihoods of black farmers after the Fast Track Land Reform Programme. Whereas, within the livelihoods perspectives it was noted that the livelihoods of farmworkers declined.
\end{abstract}

Keywords: land reform; political perspective; livelihoods perspective; agricultural productivity; human rights perspective; Zimbabwe

Sleutelwoorde: grondhervorming; politieke perspektief; lewensbestaan perspektief; landbouproduksie; menseregte perspektief; Zimbabwe

\section{INTRODUCTION}

Land reform has been implemented around the world, mostly in former colonies, using different 
approaches with varying implications. After a long period of being considered irrelevant, land reform has re-emerged in the media and political limelight - largely a result of the land reform initiatives in Zimbabwe (Derman, 2006; Moyo, 2010; Scoones, Marongwe, Mavedzenge, et al., 2011). Bill Derman articulates that, 'Zimbabwe's fast track land reform has generated significant attention in southern Africa and beyond due to its speed, scale and the forced displacement of landowners and farmworkers (Derman, 2006:1). Hentze and Menz (2015:356) aver that 'land reform in Zimbabwe has attracted extensive and ongoing attention among scholars in a number of disciplines.' Thus, it can be noted that studies on land reform in general, and Zimbabwean land reform in particular, have been exponential in recent years. A systematic review of contemporary literature on land reform in Zimbabwe reveals a number of explanatory models ranging from political, economic, agricultural and human rights perspectives.

The paper first gives a background to the land reform initiative in Zimbabwe. This is followed by a discussion on the concept of land reform. The paper concludes with an interrogation of emerging and dominant perspectives on land reform in Zimbabwe.

\section{BACKGROUND TO THE LAND REFORM IN ZIMBABWE}

To conceptualise the issue of land reform and its implications in Zimbabwe this paper focuses on identifying and analysing four dominant narratives: the political perspective, the livelihoods perspective, the human rights perspective and the agricultural perspective. Land reform in Zimbabwe traversed over three decades. The first phase of the post-independence era (1980-1999) witnessed minimal changes in land ownership in Zimbabwe. The lack of significant changes in land ownership in this phase was largely due to the 'willing seller, willing buyer' policy as stipulated in the Zimbabwean constitution. The second phase brought radical changes in the ownership of land in Zimbabwe and was known as the Fast Track Land Resettlement Programme (FTLRP). The adoption and pursuance of the FTLRP completely altered the ownership of the land by the minority white farmers to the formerly landless black farmers.

There is a need to clarify the difference between land reform and the land question in a Zimbabwean context. Mabhena (2010:iii) explained that 'land reform has been going on in Zimbabwe since the state attained independence from Britain in 1980 as a way of enhancing agrarian livelihoods for the formerly marginalised people.' Land reform in Zimbabwe has morphed in its approach over the years - from the initial 'willing seller, willing buyer' approach to the controversial and radical land reform. By contrast, the land question has unfolded over a century (Moyo, 1986; Palmer, 1990). Sachikonye (2004:3) argues that 'the 
land question essentially centred on the patterns that land distribution assumed through expropriation ...' Therefore, from the outset, there is a need to separate the background to land reform from the background to the land question. The land question entails a century-old struggle over land rights in Zimbabwe. The land question began when the British South Africa Company occupied and administered the land north of the Limpopo. The white settlers assumed self-rule in 1923 and the area became the Colony of Southern Rhodesia. ' This involved 'land alienation and deliberate restructuring of customary land tenure system of the indigenous people.' (Tshuma, 1997, cited in Sachikonye, 2004:7). It can be reasoned that the land reform is relatively younger than the land question despite spanning over three decades. Additionally, tracing land reform in Zimbabwe reveals that there is no short cut to addressing land inequity but instead it requires a gradual process.

It is important to sub-divide the era after independence in Zimbabwe in terms of the approach pursued by the government in land reform. The period from 1980 to 1999 was largely premised on adherence by the Zimbabwean government to the Lancaster House Agreement (Raftopolous \& Mlambo, 2009; Sachikonye, 2005). Raftopolous and Mlambo (2009) state that the Lancaster House Agreement put in place a framework for land redistribution and resettlement in Zimbabwe and it further availed guidelines for land ownership. The focus of this earlier period was on settling people on land on a 'willing seller, willing buyer' basis (Sachikonye, 2005). In addition, according to the Lancaster House Agreement (hereafter the 'Agreement'), the 'willing seller, willing buyer' mechanism meant that there were no impediments for white farmers wishing to continue their farming activities. (Chitsike, 2003; Dabale, Jagero \& Chiringa, 2014; Lebert, 2003). The Agreement was a compromise constitution negotiated by the liberation movement, the colonial government as well as the British government. It had restrictions in terms of land reform and constitutional amendments, for example, it forbade compulsory acquisition of land from the white farmers for ten years immediately after independence. Law argues that 'Mugabe was keen to encourage the white population to remain in Zimbabwe. This meant that radical land distribution was necessarily put on hold, being deferred for at least ten years until the Lancaster House Agreement expired' (Law, 2009:56). Therefore, the Agreement was an obstacle to land reform throughout the first decade of independence. It can be argued that the Lancaster House Agreement meant that there could not be any radical changes in land ownership in Zimbabwe in the first

$1 \quad$ Southern Rhodesia remained a British colony until 1980. In 1965, the white-minority government issued a Unilateral Declaration of Independence (UDI) and established Rhodesia (an unrecognised state). In April 1980, after a period of interim British control following the 1979 Lancaster House Agreement, the country achieved internationally recognised independence as Zimbabwe. 
decade of independence. Lloyd Sachikonye points out that due to the restrictions on land due to the agreement, "by 1989 only about 48000 households against a target of 162000 households had been resettled from the overcrowded communal lands onto new land' (Sachikonye, 2005:7). This was largely due to resource constraints to adhere to the constitutional stipulation of 'willing seller, willing buyer'. However, despite yielding poor results in terms of total land transferred, this period was generally non-violent and organised. Notably, land discourse during the period between independence and 1999 mainly revolved around the unfulfilled land pledge by the ZANU-PF government.

The period after the year 2000 marked a change in the approach that was evident in the first phase of land reform in Zimbabwe. Dabale et al. (2014:38) reveal that 'The FTLRP primary objective was to accelerate both land acquisition and redistribution.' The Chief Svosve people invasion of white-owned commercial farms in Marondera (Mashonaland East) marked the onset of the radical change in the land situation (Scoones, 2014). The centrality of the role played by Chief Svosve and his people can be utilised to argue that land reform in Zimbabwe was initiated by land-hungry peasants. However, it should be noted that initially the land invasion by Chief Svosve was temporarily halted by a government promise of a new constitution. Murisa (2011) argues that the rejection of the draft constitution in a referendum held in February 2000 reignited land occupations across the country. As a result, the referendum that saw people voting against Zanu PF's intended constitutional change became a major catalyst for land reform. From that period, land reform/redistribution acquired various names, such as Third Chimurenga (Third Revolution), ${ }^{2}$ Hondo yeminda, and jambanja. ${ }^{3}$ Sibanda and Maposa (2014:55) mention that 'the land reform programme (Third Chimurenga) is a monumental agrarian revolution in Zimbabwe, and its repercussions have been largely paradoxical to the extent that they have sent shockwaves in Africa and beyond.'

Varying statistics have been proffered on the land reform in Zimbabwe. Moyo (2011:3) states, 'across the country, the formal land re-allocation since 2000 has resulted in the transfer of land to nearly 170000 households by 2010'. Murisa (2013:251) notes, 'The Fast Track Land Reform Programme (FTLRP) has led to significant social change, with approximately 160000 families now settled in areas previously inhabited by approximately 4000 large-scale farmers.' Mandivamba Rukuni adds that 'the Fast Track Land Reform Programme, which began in 2000, allocated to new farmers over 4500 farms making up 7.6 million hectares, $20 \%$ of the total land area of the country (according to admittedly rough official figures)' (Rukuni, 2011:147). Although there is no consensus on the

$2 \quad$ Third Chimurenga and Hondo yeminda meaning the 'war for land' in the Shona language.

3 Jambanja is a newly coined Shona expression that refers to the forced takeover of white commercial farms by the indigenous people under the FTLRP. 
statistics amongst academics, it is widely accepted that the FTLRP has resulted in the transfer of $90 \%$ of land formerly owned by white farmers to the landless. Bratton and Masunungure (2011:23) state, 'between 2000 and 2002, some 11 million hectares were confiscated from 4000 white farmers...' Therefore, the FTLRP transferred land from 4000 white farmers to approximately 160000 black families. Based on these statistics, it can be argued that the land reform in Zimbabwe has managed to redress the land grievance among the poor and landless majority of black people in Zimbabwe.

The following sections consider the emerging narratives on the land reform in Zimbabwe.

\section{THE CONCEPT OF LAND REFORM}

Academics and lay scholars have all contributed to the growing discourse surrounding the concept of land reform. Kudzayi Tarisayi argues that "most scholars and development agencies are concentrating on the success or lack thereof, of land reform without interrogating the concept of land reform' (Tarisayi, 2014:195). It, therefore, becomes imperative to interrogate the concept and definition to guide any study of the concept. Martin Adams (1995:1) states that 'land reform in its simplest sense is generally accepted to mean the redistribution of property or rights in land for the benefit of the landless, tenants and farm labourers.' Additionally, Solon Barraclough elaborates:

Land reform means different things for different people and in different circumstances. For some, privatization of communal or state lands in order to make them available for commercial use, such as export crop production, is land reform. Many authorities put forward more restrictive definitions similar to that used here. Barraclough (1999:11)

Michael Lipton (2009), avers that there is a vast literature on the definition of land reform spawning prescriptive, descriptive and purposive interpretations. Additionally, Boyce, Rosset and Stanton (2005) opine that land reform has different dimensions, which include: rights, structure, security, egalitarianism, gender, compensation, and the macroeconomic environment and process. Land reform can, therefore, be revealed to vary in size in the sense that it could be widespread and covering a province or country, while it could also be gradual, initially covering small geographical areas in a country. Also, land reform can take different approaches ranging from 'land restitution, land redistribution, land tenure change and land consolidation, among others.' (Tarisayi, 2014:199). Therefore, land reform facilitates the transfer of benefits from big landowners to formerly disadvantaged and landless people. The transfer of benefits from land that has been taken over can be shared through the allocation of the land to individuals, cooperatives or state farming. In this regard, various definitions 
have been proffered on the concept of land reform. This paper adopts the conventional definition, which states, 'redistributive land reform is a public policy that transfers property rights over large private landholdings to small farmers and landless farmworkers' (Tarisayi, 2014:196). Additionally, the paper recognises the role of land reform in addressing land inequity due to the colonial legacy. Colonial rule had left relics in the form of skewed land ownership in Zimbabwe. The next section provides the context of the land reform initiative in Zimbabwe.

\section{PERSPECTIVES ON LAND REFORM IN ZIMBABWE}

This section investigates different perspectives on land reform in Zimbabwe, namely, the political perspective, the human rights perspective, the agricultural productivity perspective and the livelihoods perspective.

\subsection{The political perspective on land reform in Zimbabwe}

This section analyses various views proposing that the land reform in Zimbabwe was executed for political reasons. However, it should be noted that despite the paper's classification of these views into one narrative, it does entail consensus by the views. The realisation that it is difficult to separate politics and the land in Zimbabwe led Scoones et al. (2011:17) to concede that 'land and politics are deeply intertwined in Zimbabwe.' It can be argued that due to the intricacy between the land and politics in Zimbabwe, any discussion on land reform needs to be informed by the political perspective.

One prominent view within the political perspective holds that the ruling party (ZANU-PF) used the land reform to gain political mileage. Events immediately prior to the land occupations, such as the formation of the opposition party (MDC), as well as the February 2000 referendum, support the view that ZANU-PF's power was under threat from the opposition. Rukuni argues that 'the land issue was brought back to the centre stage by the growing political opposition to ZANU-PF, which eventually saw the formation of the Movement for Democratic Change (MDC), disgruntled communities in Matebeleland, white farmers and other opposition groups' (Rukuni, 2011:147). The rejection of the draft constitution in the February 2000 referendum forced ZANU-PF to panic because the country was scheduled to have parliamentary elections in June 2000. The newly formed MDC as well as civic society had strongly campaigned for the rejection of the draft. The rejection in the referendum was seen as a warning of what seemed to be an inevitable defeat of ZANU-PF in the parliamentary elections. As a result, "the land issue became an issue of political survival in an election year.' (Sachikonye, 2005:9). The land appetite was manipulated to resuscitate the electoral prospects of ZANU-PF. Makumbe (2009:05) states, 
'the so-called Third Chimurenga (Third Revolution) that began in 2000 was propagated by the Mugabe regime as a logical sequel to the first and second revolutions to liberate Zimbabwe from colonial forces and injustices.' Makumbe also declares, 'stung by the public rejection of the government-sponsored draft constitution in February 2000, the Mugabe regime mobilised thousands of war veterans, unemployed young people and rural peasants to invade white-owned commercial farms throughout the country' Makumbe (2009:7).

This paper concedes that there was a demand for land in Zimbabwe prior to the FTLRP. This demand for land was utilised by ZANU-PF, backed by war veterans, to ensure electoral victory at the polls. Additionally, there is both historical and contemporary evidence that ZANU-PF used the land acquisition to spite perceived political opponents. The acquisition of farms belonging to opposition political figures, such as Rev. Ndabaningi Sithole's Churu Farm and James Chikerema, in the 1990s, under the auspices of the law aptly buttresses this argument. Hence, using this historical evidence it can be revealed that in 2000, ZANU-PF resorted to the same strategy and pursued the FTLRP in order to punish the white farmers perceived to be supporters of the MDC. This is supported by Mapuva and Muyengwa-Mapuva (2014:16) who note that 'the land issue has also been used as a retributive measure to punish those who did not support the ruling party.' It can be reasoned from historical and contemporary evidence that the ZANU-PF government manipulated the land to spite perceived opponents and to curb dissent both within and outside the ruling party. White farmers were viewed as sponsors and supporters of the opposition party. Land occupations were thus proxy attacks on the support base of the opposition MDC party. The reasoning for this being that redistribution of the land would render the white farmers unable to fund and support the MDC. It is, therefore, not coincidental that land occupations occurred in 2000 when ZAN-PF's support was waning and under the threat from the MDC.

Another interesting insight within the political perspective to the Zimbabwean land reform is premised in the 'instrumentalization of disorder' thesis. Chabal and Daloz (1999:10) argue that 'the instrumentalization of disorder is when the state is utilised as the instrument of primitive accumulation which is achieved through the monopoly seizure of the means of production by political elites.' This paper borrows from this Chabal and Daloz concept of instrumentalization of disorder and argues that the land reform was a veneer for the looting of properties owned by white farmers. Bratton and Masunungure concur and point out:

[While] some landless individuals received plots of land under the socalled 'fast track' land reform programme, other land invaders were 
later ejected to make way for ZANU-PF chefs, ${ }^{4}$ some of whom now own several farms. (Bratton \& Masunungure, 2011:23)

Multiple farm ownership and the eviction of black farmers initially allocated the land to make way for political elites further support the argument that land reform provided a veneer for looting. However, the instrumentalisation of the disorder can be critiqued using revelations by Scoones et al. (2010) and Marongwe (2008) that politicians and government officials only make about $10 \%$ of the land beneficiaries.

The next section discusses the human rights perspective on land reform in Zimbabwe.

\subsection{The human rights perspective on land reform in Zimbabwe}

Various views informed by both domestic and international legal instruments are classified in this paper under the human rights perspective. The central argument holds that the FTLRP violated private property rights of the white farmers as enshrined in the constitution of Zimbabwe. Mabhena (2010:91) avers that 'the politicization of the land reform programme has seen property rights on land being violated.' At the time, the Zimbabwean government were scornful of both domestic and regional court rulings and any attempts by the aggrieved white farmers to seek legal recourse were met with contempt by The SADC Tribunal ruled that the private property rights of the white farmers were violated in Mike Campbell (Pvt) Ltd and Others v Republic of Zimbabwe (2/2007). However, the Zimbabwean government ignored the ground-breaking ruling by the SADC Tribunal (SADC, 2008). The Human Rights Watch (2008:25), narrates: 'On 17 March 2000, Justice Paddington Garwe declared that the "invasion" of a number of farms by squatters, claiming to be veterans of Zimbabwe's liberation war, was unlawful.' It can be argued that there was consensus at the time between domestic and regional courts that the private property rights of white farmers were violated. The contempt of court was aptly revealed when the president at that time, Robert Mugabe said:

The courts can do whatever they want, but no judicial decision will stand in our way ... My own position is that we should not even be defending our position in the courts. We cannot brook interference by court impediment to the land acquisition programme. (Mugabe, cited in Justice for Agriculture Zimbabwe, 2008:2)

The government was critical of the court rulings and argued that the courts were compromised and supported white farmers. To further confirm that the private property rights of the white farmers had been violated, the government

$4 \quad$ The word 'chefs' was informally used for senior members of the ZANU-PF. 
amended the constitution of Zimbabwe in 2005 to apply retrospectively. Constitutional Amendment Number 17 of 2005 legalised the land acquisitions that had already taken place prior to the passing of the amendment. It was a tacit admission of guilt by the government that private property rights had been violated.

Additionally, contempt of the judiciary was evident in the invasion of the Supreme Court. Former Chief Justice Anthony Gubbay narrates: "[0]n 24 November 2000, "war veterans" forcibly entered the Supreme Court building shouting ZANU-PF political slogans and calling for judges to be killed' (Human Rights Watch, 2008). That the Chief Justice was threatened within the Supreme Court building by war veterans was the pinnacle of the contempt of court. This paper argues that the invasion of the Supreme Court was a clear message to white farmers and all sympathisers that the war veterans deemed that no one was untouchable. Due to the invasion of the Supreme Court, the Chief Justice was forced to resign as the government could no longer guarantee his safety. The resignation of the Chief Justice was followed by more executive interference in the judiciary. This interference was reflected in the sacking of a number of judges and replacing them with others more sympathetic to land reform and re-enactment of pro-squatter legislation' (Mamdani, 2008:17). Among the sympathetic judges who were elevated was retired Brigadier General George Chiweshe, a war veteran and black farmer. Consequently, it can be argued that the government utilised a constitutional amendment and appointment of sympathetic judges to legalise the violation of the private property rights of the white farmers.

Another view with the human rights perspective points to the use of violence during the FTLRP. Robert Mugabe supported the use of violence and declared that 'it is perfectly justifiable to use necessary force to overcome resistance to the transformation of the economy in favour of the black majority to achieve economic justice' (Justice for Agriculture Zimbabwe, 2008:2). It can be argued that the approach to Zimbabwe's land reform as evidenced by threats to the judiciary was a gross contempt of the courts. As Moyo explains:

$[T]$ he main controversy in the land reform debate today is over the physical violence and the violation of property rights of landowners and of farmworkers, which the militant and state-led approach pursued, having suspended certain land-related laws and 'rights' in order to reverse past injustices. (Moyo, 2006:345)

According to this view, the land reform initiative in Zimbabwe was violent and did not respect private property rights, right to life, and living secure lives. However, this view fails to appreciate that the white farmers were beneficiaries of the illegal dispossession of land previously occupied by the ancestors of the 
poor and landless black majority in Zimbabwe. Neither does the human rights narrative apply itself to the violence that was associated with the dispossession of the land a century earlier after the Anglo-Ndebele War of Dispossession of 1893-94. Moreover, it can be argued that the property rights of the white farmers that were violated were actually protected by the disputed Lancaster House Constitution. Despite the expiry of the Lancaster House Agreement clause and the various amendments to the Constitution of Zimbabwe prior to Constitutional Amendment Number 17, the Constitution was still a compromise document. The Constitution had been crafted during the independence negotiations to maintain the status quo in land ownership. The land reform was executed to correct a historical injustice, which erroneously gave the white farmers property rights in the first place. The next section widens the discussion on the land reform in Zimbabwe to interrogate the agricultural productivity perspective.

\subsection{The agricultural productivity perspective}

Other views on the land reform in Zimbabwe compare agricultural yields in general, and maize production in particular, before and after the FTLRP. The comparison of yields in this paper is largely grounded in economics and economic theory. A comparison of yields by Derman (2006) and Zikhali (2008) suggests that after the FTLRP there was a decline in horticulture and the production of maize, cotton, tobacco and citrus. Zikhali (2008:5) uses an 'econometric framework and estimation strategy to argue that the productivity of the Fast Track Land Resettlement Programme beneficiaries fell short of the levels demonstrated by the commercial farming sector prior to the land reform.' Derman (2006:06) states that 'the leading export crop, tobacco, yielded 55 tons for the international market in 2005 compared to 240 tons prior to fast track [the land reform programme].' These statistics suggest a decline of more than $400 \%$ in tobacco production. In addition, Chisango and Obi state, 'not long after the launch of the Fast Track Land Resettlement Programme (FTLRP), it became clear that the expectations had been exuberant as production declined dramatically and only about 30 to $55 \%$ of the arable land was being cultivated' (Chisango \& Obi, 2010:2). Additionally, Hawkins (2013) argues that in '2000,5 Zimbabwean farms produced 3.7 million tonnes of output (excluding estate-grown sugar).' In 2012, the Ministry of Finance acknowledged a harvest of less than 1.7 million tonnes. Matereke (2009:94) diagnoses that 'after the ZANU-PF chaotic land reform in which productive land was grabbed from the white farmers, Zimbabweans began to experience an endemic food crisis.'

The statistics given here buttress the view that indeed there was a decline in crop production in Zimbabwe after the FTLRP. However, this paper argues 
that it is difficult to ascertain the crop production statistics after the FTLRP due to reliance on estimates. The black farmers who benefited from the FTLRP follow a communal lifestyle and a subsistence approach to farming. Unlike the commercial farmers prior to the land reform, who sold their produce in the formal marketing system, the black farmers sell their products mostly through informal markets and social networks (extended family and friends). It can, therefore, be reasoned that not selling externally does not necessarily translate into poor agricultural productivity. This poses data limitations as the participation of black farmers in farming for export is still in its infancy. Data limitations on the implications of land reform were also witnessed in the Chinese land reform of 1947-1952. Bramall (2004:109) suggests that 'it is difficult to delineate the precise impact of land reform on Chinese income distribution because of data limitations.' Therefore, it can be argued that due to data limitations the reliance on statistics within this perspective is its main weaknesses.

However, the agricultural productivity perspective can be critiqued for passing premature assessments of the viability of agriculture in Zimbabwe after the FTLRP. Rukuni (2011:149) comments that 'it took about 40 years to establish viable large-scale agriculture in Zimbabwe (1910-1950).' The establishment of a viable agriculture sector was created through immense state support ranging from money, research and development, information, farmer training and subsidies related to energy, irrigation development and water development. This paper argues that agricultural productivity after the FTLRP requires time and investment to equal or even surpass the 1990s statistics. Additionally, contemporary studies already suggest a recovery in the agricultural sector in Zimbabwe. Scoones, Mavedzenge, Murimbarimba et al. (2018:9) reveal, 'tobacco production slumped to a low of $55500 \mathrm{~kg}$ in 2006 but increased to $216000 \mathrm{~kg}$ in 2014, reaching pre-reform levels. Estimated production in 2017 was 185600 kg.' It can be acknowledged that agricultural production initially slumped immediately after the FTLRP, but statistics indicate an improvement in crop production. Matondi (2012), Tarisayi (2016) and Tarisayi and Manik (2017) established that the black farmers who benefited from the FTLRP are investing in schools from proceeds from their farms. It can be argued that despite struggling to produce in the first decade after the FTLRP, the agricultural output of black farmers has improved. This is shown by statistics of tobacco production.

The next section discusses the livelihoods perspective on land reform in Zimbabwe. This is a derivative and extension of the agricultural productivity perspective. 


\subsection{The livelihoods perspective on land reform in Zimbabwe}

This paper classifies studies that strive to assess the impact of the FTLRP on the way that people make a living are classified under the livelihoods perspective. Seminal scholars, Chambers and Conway (1992:9), offer that 'a livelihood comprises the capabilities, assets and activities required for a living.' Any discussion on the land reform in Zimbabwe is incomplete without investigating the implications of the FTLRP on the way that farmworkers and the black farmers, among other groups, make a living. This paper is confined to a discussion on the livelihoods of farmworkers and the black farmers who were among the groups directly related to the land. White farmers who were forced off the land opted to migrate to urban areas or leave for countries such as Zambia, South Africa, Australia or the United Kingdom. So, despite the livelihoods of white farmers being affected, they are not part of this discussion.

One informing view stems from the question, 'what happened to people's livelihoods once they got land through the 'fast-track' programme from 2000?' (Scoones et al., 2010:1). There is a tendency to generalise that there was a decline in the livelihoods in Zimbabwe due to the FTLRP. However, empirical evidence suggests that the discussion on what happened to livelihoods after the land reform is more complicated. Scoones et al. (2011:1) argue, 'the story is not simply one of collapse and catastrophe; it is much more nuanced and complex, with successes as well as failures.' Different case studies have reached conflicting conclusions. For example, the case studies by lan Scoones (2016) on Mvurwi, and by Tarisayi and Manik (2017) on Masvingo establish that the livelihoods of the black farmers had improved. However, in a case study on Matebeleland, Mabhena argues, 'there is an increase in hectares but vanishing livelihoods among the land reform beneficiaries' (Mabhena, 2010:iii). The cited case studies reveal that there is no consensus on what happened to the livelihoods of the black farmers who were allocated land from the FTLRP. The fate of the livelihoods of the black farmers varies from one farm to another (size of the farm, type of crops being grown and more importantly resources at the disposal of the black farmer). While there were cases of black farmers struggling as reported by Mabhena (2010), there are also success stories as suggested by Scoones (2016), and Tarisayi and Manik (2017).

Another aspect within the livelihoods perspective entails analysing the impact of land reform on farmworkers. According to Mamdani (2008:02), 'the second casualty of the land reform in Zimbabwe after the white farmers were the farm labourers.' About 300000 farm labourers, most of them migrant labour, were displaced by the FTLRP, mainly because of their nationality. It can, therefore, be reasoned that the livelihoods of the farmworkers who were displaced by the land reform process were negatively affected to a greater extent. 
Sachikonye concludes that "the outcome of the programme has been the loss of jobs and livelihoods by farmworkers ... and the acquisition of land as a resource by several hundred thousand small farmers and black commercial farmers' (Sachikonye, 2003:2). Hence, within the livelihoods perspective of Zimbabwe's land reform, it is suggested that while the farmworkers lost their livelihoods, several hundred thousand A1 and A2 farmers' livelihoods were enhanced by the land reform. This perspective reveals that there are indeed both negative and positive impacts on the livelihoods of black farmers as put forwarded by empirical data reviewed. Hence, it follows within this livelihood perspective that farmworkers can be seen as collateral damage, while white farmers can be viewed as the major victims of the land reform.

\section{CONCLUSION}

This paper has shown that there are many views and perspectives on land reform in Zimbabwe. It was interesting to note that within the same perspective there are varying views. Some views in the political perspective in this study argued that the demand for land was manipulated by the ZANU-PF government for political mileage. This paper has also shown that it is difficult to separate politics and the land in the history of Zimbabwe. Another perspective discussed was agricultural productivity, which derives from economics and economic theory. Views within the agricultural productivity initially suggested a decline in crop production using a comparison of statistics before and after the FTLRP. However, recent studies suggest that the agricultural productivity by black farmers has improved to match the statistics of some crops (for example tobacco) prior to the FTLRP. The other narrative is guided by the Constitution, as well as domestic and regional legal instruments to argue that the FTLRP violated the private property rights of the white farmers. There was also contempt of court during and after the FTLRP as court rulings were ignored by the government. Finally, in the discussion on the livelihoods perspective, the paper showed that there was a consensus that the livelihoods of the farmworkers were negatively affected by the FTLRP. However, case studies referred to in the paper revealed that there were both successes and failures in the livelihoods of the black farmers after the FTLRP.

\section{REFERENCES}

Adams, M 1995. "Land reform: New seeds on old ground?", Natural Resource Perspectives, 6(October).

Barraclough, SL 1999. Land reform in developing countries: The role of the state and other actors. Geneva: UNRISD. 
Boyce, JK \& P Rosset \& EA Stanton 2005. Land reform and sustainable development. Political Economy Research Institute Working Paper Series No. 98.

Bramall, C 2004. "Chinese Land reform in long-run perspective and in the wider East Asian concept", Journal of Agrarian Change, 4(1):107-141. https://doi. org/10.1111/j.1471-0366.2004.00074.x

Bratton, M \& E Masunungure 2011. The anatomy of political predation: leaders, elites and coalitions in Zimbabwe, 1980-2010. Developmental Leadership Programme Research Paper No. 9.

Chabal, P \& J Daloz 1999. Africa works: Disorder as political instrument. Bloomington IN: Indiana University Press.

Chambers, R \& GR Conway1992. Sustainable rural livelihoods: Practical concepts for the 21st Century. Institute of Development Studies Discussion Paper No. 296: 1-33.

Chisango, FF \& A Obi 2010. Efficiency effects Zimbabwe's agricultural mechanization and Fast Track Land Reform Programme: A stochastic frontier approach. Paper presented at the Joint 3rd African Association of Agricultural Economists (AAAE) and 48th Agricultural Economists Association of South Africa (AEASA) Conference, Cape Town, South Africa, 19 to 23 September 2010.

Chitsike, F 2003. A critical analysis of the land reform programme in Zimbabwe. Retrieved from <http://www.fig.net/pub/morocco/proceedings/T54/T54-4chitsike.pdf>, accessed 31 January 2016.

Dabale, WP \& N Jagero \& C Chiringa 2014. "Empirical study on the Fast Track Land Reform Programme (FTLRP) and household food security in Zimbabwe", European Journal of Research and Reflection in Management Sciences, 2(2):37-42.

Derman, B 2006. "After Zimbabwe's Fast Track Land Reform: Preliminary observations on the near future of Zimbabwe's efforts to resist globalization", Montpellier:1-29.

Hawkins, T 2013. "Zimbabwe land reform: How successful?" Issue of Welt-Sichten. Retrieved from <http://www. weltsichen.de/>, accessed 20 May 2016.

Hentze, K \& G Menz 2015. "Bring back the land: A call to refocus on the spatial dimension of Zimbabwe's land reform", Land, 4:355-377. https://doi. org/10.3390/land4020355

Human Rights Watch 2008. "Our hands are tied: Erosion of the rule of law in Zimbabwe", Human Rights Watch, 8 November. Available at <https://www. refworld.org/docid/4917f56a2.htm>, accessed 30 June 2019.

Justice for Agriculture Zimbabwe 2008. Destruction of Zimbabwe's backbone industry in pursuit of political power. Report prepared by the Justice for 
Agriculture Trust (JAG) and the General Agricultural and Plantation Workers Union of Zimbabwe (GAPWUZ).

Law, K 2009. "Episodes of ambiguity: Steps towards socialism in Zimbabwe, 1980-1985", African Studies Association of Australasia and the Pacific, 30(1):49-63.

Lebert, T 2003. An introduction to land and agrarian reform in Zimbabwe. Retrieved from <http://www.cerai.es/fmra/archive/lebert.pdf>, accessed 31 January 2016.

Lipton, M 2009. Land reform in developing countries: Property rights and property wrongs. London: Routledge. https://doi.org/10.4324/9780203876251

Mabhena, C 2010. Visible hectares, vanishing livelihoods: A case of the Fast Track Land Reform and Resettlement Programme in Southern Matabeleland Zimbabwe. PhD thesis, University of Fort Hare, Alice, South Africa.

Makumbe, J 2009. Zimbabwe: Political context study, human rights, power, and civic action. Oslo: RIPOCA.

Mamdani, M 2008. "Lessons of Zimbabwe", London Review of Books, 30:17-21.

Mapuva, J \& L Muyengwa-Mapuva 2014. "The troubled electoral contestation in Zimbabwe", International Journal of Political Science and Development, 2(2):15-22. https://doi.org/10.12966/ijplr.06.01.2014

Marongwe, N 2008. Interrogating Zimbabwe's Fast Track Land Reform and Resettlement Programme: A focus on beneficiary selection. Master's dissertation, University of Western Cape, Cape Town, South Africa.

Matondi, PB 2012. Zimbabwe's Fast Track Land Reform. London: Zed Press.

Matereke, K 2009. "Discipline and Punish: Inscribing the Body and its Metaphors in Zimbabwe's Postcolonial Crisis", African Studies Association of Australasia and the Pacific, 30(1):83-100

Moyo, S 1986. "The land question", in I Mandaza, ed., Zimbabwe: The political economy of transition (1980-1986). Harare: CODERSIA Book Series.

Moyo, S 2006. Land redistribution and public action in Zimbabwe. Paper presented at an international symposium on At the frontier of land issues: Social embeddedness of rights and public policy, Montpelier, 17-19 May. Retrieved from <www.aiastrust.org>, accessed 30 January 2016.

Moyo, S 2010. "The Zimbabwe crisis, land reform and normalisation", in . In Anseeuw W \& C Alden, eds., The struggle over land in Africa: Conflicts, politics and change. Cape Town: HSRC Press.

Moyo, S 2011. "Three decades of agrarian reform in Zimbabwe", Journal of Peasant Studies 38(3):493-531. https://doi.org/10.1080/03066150.2011.583642 
Murisa, T 2011. "Lacuna in rural agency: The case of Zimbabwe's agrarian reforms", in Helliker K \& T Murisa, eds., Land struggles and civil society in southern Africa (1st edition). Trenton, NJ: Africa World Press, pp. 113-154.

Murisa, T 2013. "Social organisation in the aftermath of 'Fast Track': An analysis of emerging forms of local authority, platforms of mobilisation and local cooperation" in Moyo S \& W Chambati, eds., Land and agrarian reform in Zimbabwe: Beyond white-settler capitalism. Harare: African Institute for African Studies; Dakar: Council for the Development of Social Research in Africa. https://doi.org/10.2307/j.ctvk3gnsn.13

Palmer, R 1990. "Land reform in Zimbabwe 1980-1990", African Affairs, 89:163-180. https://doi.org/10.1093/oxfordjournals.afraf.a098283

Raftopoulos, B \& A Mlambo 2009. "Becoming Zimbabwe: A history from the precolonial period to 2008", Review of African Political Economy, 37(125):392393. https://doi.org/10.1080/03056244.2010.511938

Rukuni, M 2011. "The Land issue and the inclusive government", Zimbabwe at the crossroads, 1(1):147-150.

Sachikonye, LM 2004. "The promised land: From expropriation to reconciliation and Jambanja", in Raftopoulos B \& T Savage, eds., Zimbabwe: Injustice and political reconciliation. Cape Town: Institute for Justice and Reconciliation.

Sachikonye LM 2005. "The land is the economy: Revisiting the land question", African Security Review, 14(3):32-44. https://doi.org/10.1080/10246029.20 05.9627368

Sachikonye, LM 2003. Land reform for poverty reduction? Social exclusion and farmworkers in Zimbabwe. Paper presented at the IDMP conference, Staying poor: Chronic poverty and development policy, Manchester University, Manchester, 7 to 9 April.

SADC 2008. Second ruling of the SADC Tribunal (Case No. SADC - T2/08). Windhoek: Southern African Development Community Tribunal.

Scoones, I 2014. "Zimbabwe's land reform: new political dynamics in the countryside", Review of African Political Economy, 42(144):190-205. https:// doi.org/10.1080/03056244.2014.968118

Scoones, I 2016. Mvurwi: From farmworker settlement to booming business centre. Retrieved from <https://zimbabweland.wordpress.com/2016/05/16/1654>, accessed. 31 January 2016.

Scoones, I \& N Marongwe \& B Mavedzenge \& F Murimbarimba \& J Mahenehene \& C Sukume 2010. Zimbabwe's land reform: Myths and realities. Harare: Weaver Press. 
Scoones, I \& N Marongwe \& B Mavedzenge \& F Murimbarimba \& J Mahenehene \&

C Sukume 2011. Zimbabwe's land reform: A summary of findings. Brighton, UK: Institute of Development Studies.

Scoones, I \& N Marongwe \& B Mavedzenge \& F Murimbarimba \& I Mahenehene \& C Sukume 2018. "Labour after land reform: The precarious livelihoods of former farmworkers in Zimbabwe", Development and Change, 50(3): 1-31. https:// doi.org/10.1111/dech.12449

Sibanda, F \& RS Maposa 2014. "Beyond the Third Chimurenga? Theological reflections on the land reform programme in Zimbabwe, 2000-2010", The Journal of Pan African Studies, 6(8):54-74.

Tarisayi, KS 2014. "Land reform: An analysis of definitions, types and approaches", Asian Journal of Agriculture and Rural Development, 4(3):195-199.

Tarisayi, KS 2016. The social capital influences of land reform beneficiaries and communal farmers on satellite schools in Zimbabwe. PhD thesis, University of Kwazulu-Natal, South Africa.

Tarisayi, KS \& S Manik 2017. "Social networks among land reform beneficiaries and their use in supporting satellite schools in Zimbabwe: A case study of a satellite school", Education as Change, 21 (3):1-17. https://doi.org/10.17159/19479417/2017/2091

Zikhali, P 2008. "Fast track land reform and agricultural productivity in Zimbabwe", Economics, 322:1-32. 